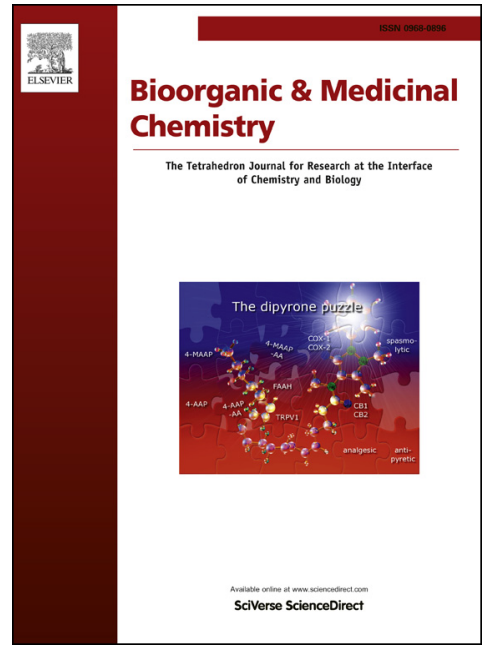

Synthesis of 1,2-Benzisoxazole Tethered 1,2,3-Triazoles That Exhibit Anticancer Activity in Acute Myeloid Leukemia Cell Lines by Inhibiting Histone Deacetylases, and Inducing p21 and Tubulin Acetylation

Nanjundaswamy Ashwini, Manoj Garg, Chakrabhavi Dhananjaya Mohan, Julian E. Fuchs, Shobith Rangappa, Sebastian Anusha, Toreshettahally Ramesh Swaroop, Kodagahalli S. Rakesh, Deepika Kanojia, Vikas Madan, Andreas Bender, H. Phillip Koeffler, Basappa, Kanchugarakoppal S. Rangappa

PII: S0968-0896(15)00653-7

DOI: http://dx.doi.org/10.1016/j.bmc.2015.07.069

Reference: BMC 12498

To appear in: Bioorganic \& Medicinal Chemistry

Received Date: 3 June 2015

Revised Date: 29 July 2015

Accepted Date:

30 July 2015

Please cite this article as: Ashwini, N., Garg, M., Mohan, C.D., Fuchs, J.E., Rangappa, S., Anusha, S., Swaroop, T.R., Rakesh, K.S., Kanojia, D., Madan, V., Bender, A., Phillip Koeffler, H., Basappa, Rangappa, K.S., Synthesis of 1,2-Benzisoxazole Tethered 1,2,3-Triazoles That Exhibit Anticancer Activity in Acute Myeloid Leukemia Cell Lines by Inhibiting Histone Deacetylases, and Inducing p21 and Tubulin Acetylation, Bioorganic \& Medicinal Chemistry (2015), doi: http://dx.doi.org/10.1016/j.bmc.2015.07.069

This is a PDF file of an unedited manuscript that has been accepted for publication. As a service to our customers we are providing this early version of the manuscript. The manuscript will undergo copyediting, typesetting, and review of the resulting proof before it is published in its final form. Please note that during the production process errors may be discovered which could affect the content, and all legal disclaimers that apply to the journal pertain. 


\section{Synthesis of 1,2-Benzisoxazole Tethered 1,2,3-Triazoles That Exhibit Anticancer Activity in Acute Myeloid Leukemia Cell Lines by Inhibiting Histone Deacetylases, and Inducing p21 and Tubulin Acetylation}

Nanjundaswamy Ashwini ${ }^{\mathrm{a}, \#}$, Manoj Garg ${ }^{\mathrm{b}, \#}$, Chakrabhavi Dhananjaya Mohan ${ }^{\mathrm{a}}$, Julian E. Fuchs $^{c}$, Shobith Rangappa ${ }^{\mathrm{d}}$, Sebastian Anusha ${ }^{\mathrm{e}}$, Toreshettahally Ramesh Swaroop ${ }^{\mathrm{a}}$,

Kodagahalli S. Rakesh, ${ }^{a}$ Deepika Kanojia ${ }^{\mathrm{b}}$, Vikas Madan ${ }^{\mathrm{b}}$, Andreas Bender ${ }^{\mathrm{c}}$, H. Phillip Koeffler $^{\mathrm{b}}$, Basappa ${ }^{\mathrm{e}}$, Kanchugarakoppal S. Rangappa ${ }^{\mathrm{a}^{*}}$

${ }^{a}$ Department of Studies in Chemistry, University of Mysore, Manasagangotri, Mysore-570 006, India;

${ }^{b}$ Genomic Oncology Programme, Cancer Science Institute of Singapore, National University of Singapore, Singapore-117 599;

${ }^{c}$ Centre for Molecular Science Informatics, Department of Chemistry, University of Cambridge, Lensfield Road, CB2 1EW, Cambridge, United Kingdom;

${ }^{d}$ Frontier Research Center for Post-genome Science and Technology Hokkaido University, Japan

${ }^{e}$ Laboratory of Chemical Biology, Department of Chemistry, Bangalore University, Palace Road, Bangalore-560001, India.

\#Contributed Equally.

\section{* Corresponding Author}

Prof. K.S. Rangappa

Department of Studies in Chemistry

University of Mysore

Manasagangotri

Mysore- 570005.

Karnataka, INDIA

Phone: +91-821-2419666

Tele/Fax: +91-821-2419363

Email: rangappaks@yahoo.com 


\section{Abstract}

1,2,3-triazole-based heterocycles have previously been shown to possess significant anticancer activity in various tumor models. In the present study, we attached a 1,2,3-triazole moiety to the third position of a 1,2-benzisoxazole heterocycle via Copper (I)-catalyzed azide-alkyne cycloaddition (CuAAC) with various alkynes and established for the title compounds significant antiproliferative effect against human acute myeloid leukemia (AML) cells. Among the tested compounds, 3-(4-(4-phenoxyphenyl)-1H-1,2,3-triazol-1yl)benzo[d]isoxazole (PTB) was found to be the most potent antiproliferative agent with an $\mathrm{IC}_{50}$ of $2 \mu \mathrm{M}$ against MV4-11 cells using MTT assay. Notably, PTB induced cytotoxicity in MOLM13, MOLM14 and MV4-11 cells with selectivity over normal bone marrow cells (C57BL/6). Furthermore, PTB was found to induce cytotoxicity by increasing apoptosis of AML cells (MOLM13, MOLM14 and MV4-11) as well as sub-G1 cell population and apoptotic cells at submicromolar concentrations, as shown by flow cytometry and Annexin-V staining, respectively. On the protein level we suggested histone deacetylases (HDACs) as the potential protein target of those compounds in silico, and the predicted target was next experimentally validated by measuring the variations in the levels of $\mathrm{p} 21$, cyclin $\mathrm{D}$ and acetylation of histone H3 and tubulin. Molecular docking analysis of the title compounds with the second deacetylase domain of HDAC6 displayed high degree of shape complementarity to the binding site of the enzyme, forming multiple molecular interactions in the hydrophobic region as well as a hydrogen bond to the phenol side-chain of Tyr-782. Thus, 1,2,3-triazole derivatives appear to represent a class of novel, biologically active ligands against histone deacetylases which deserve to be further evaluated in their applications in the cancer field.

Keywords: Histone Deacetylase; 1,2,3-Triazoles; Histone 3 Acetylation; Acute Myeloid Leukemia. 


\section{Introduction}

Transformation of normal cell to cancerous can be due to deregulation in proliferation, differentiation, apoptosis and epigenetic modifications. ${ }^{1}$ The significance of epigenetics in progression of various cancers especially in relevance to the role of histone deacetylase (HDAC) in oncogenesis has been well-demonstrated ${ }^{2,3}$ and implementation of histone deacetylase inhibitors (HDI) is of great appreciation since the discovery of sodium butyrate. ${ }^{4-6}$ Histone deacetylases are chromatin remodelling enzymes able to deacetylate lysine residues present on histones, with the effect of regulating gene transcription. ${ }^{7}$ The effect of this acetylation or deacetylation is rather profound - in cancer cells it has been found that HDAC inhibition modulates the transcriptional activity of about $1-2 \%$ genes. ${ }^{8}$ Extensive research on the discovery of HDIs resulted in the development of several small molecules as anticancer agents. ${ }^{9,}{ }^{10}$ Varinostat and romidepsin are the FDA approved HDIs approved for the treatment of cutaneous $\mathrm{T}$ cell lymphoma and currently many more HDIs are in clinical trials. $^{11,12}$ Many of these HDIs are reported to induce their anticancer effect by modulating both the acetylation of histones via their primary effects on HDACs, but many of them have also been found to modulate non-histone proteins, including tubulin. ${ }^{13}$

Triazole derivatives have been proved to possess various pharmacological properties including antiproliferative, antiretroviral, antimicrobial, anticonvulsant and transforming growth factor $\beta 1$ type 1 receptor inhibition. ${ }^{14-19}$ In addition, 3-substitued-1,2-benzisoxazoles have been used as prodrugs in medicinal chemistry, in which 1,2-benzisoxazole phosphorodiamidates are known to act as prodrugs of phosphoramide mustard that require bioreductive activation. ${ }^{20,21}$ Also, benzisoxazole was evaluated for their ability to function as substrates for recombinant human $\mathrm{NAD}(\mathrm{P}) \mathrm{H}$ :quinone oxidoreductase that upregulated in cancer cells. ${ }^{22}$ In continuation of our effort to synthesize various bioactive heterocycles including 3-substituted-1,2-benzisoxazole compounds, ${ }^{23-33}$ we in this work report the 
synthesis of a novel series of 1,2,3-triazoles tethered to the third position of the 1,2benzisoxazole heterocycle, and furthermore examined their cytotoxic effect on cervical cancer and acute myeloid leukemia (AML) cells. The synthesis, biological evaluation, as well as computational and experimental mode-of-action analysis of those compounds is described in the following

\section{Materials and Methods}

\subsection{Chemistry}

Melting points were determined on a Selaco melting point apparatus and are uncorrected. Infrared spectra were recorded on a Shimadzu FT-IR model 8300 spectrophotometer. ${ }^{1} \mathrm{H}$ NMR spectra were recorded on an NMR spectrometer operating at $400 \mathrm{MHz}$ using TMS as internal standard. Mass spectra were recorded using electron spray ionization mass spectrometry. Elementary analysis was performed using a CE-400 CHN analyser. Reactions were monitored by TLC using pre-coated sheets of silica gel G/UV-254 of $0.25 \mathrm{~mm}$ thickness (Merck 60F254) using UV light for visualization.

All chemicals were obtained from Sigma-Aldrich, Fluka and Merck Chemicals

\subsubsection{General procedure for the synthesis of benzisoxazole-3-azide 3:}

Benzisoxazole-3-amine $2(2.68 \mathrm{~g}, 20 \mathrm{mmol})$ was dissolved in water $(25 \mathrm{ml})$ and concentrated $\mathrm{HCl}(12.5 \mathrm{ml})$ under vigorous stirring in an ice/water bath. A freshly prepared, ice-cold solution of $\mathrm{NaNO}_{2}(1.4 \mathrm{~g}, 20 \mathrm{mmol})$ in water $(10 \mathrm{ml})$ was added drop wise to the reaction mixture by keeping the internal temperature between $0-5^{\circ} \mathrm{C}$. After the completion of addition, the reaction mixture was stirred for an additional 10min. A freshly prepared solution of sodium azide $(1.3 \mathrm{~g}, 20 \mathrm{mmol})$ in water $(10 \mathrm{ml})$ was added drop wise to the reaction mixture via an additional funnel while keeping the internal temperature of the reaction mixture below $5{ }^{\circ} \mathrm{C}$. Upon complete addition of the sodium azide solution, the reaction 
mixture was stirred for an additional $20-30 \mathrm{~min}$ at $0{ }^{\circ} \mathrm{C}$, followed by stirring at room temperature for another $3 \mathrm{~h}$. The reaction mixture was extracted with ethyl acetate EtOAc (25 $\mathrm{ml})$ three times. The combined organic layer was washed with water $(25 \mathrm{ml})$ and brine $(25$ $\mathrm{ml}$ ), dried over anhydrous sodium sulphate and concentrated under reduced pressure to get crude benzisoxazole-3-azide $\mathbf{3}$, which was purified by column chromatography over silica gel (60-120 mesh) using hexane:EtOAc (8:2) as eluent. The pure benzisoxazole-3-azide 3 was stored at $2-5^{\circ} \mathrm{C}$ in the refrigerator.

\subsubsection{General procedure for the synthesis of 1 -(3-benzisoxazolyl)-4-aryl-1,2,3-triazoles} 5a-f:

To the stirred solution of benzisoxazole-3-azide $3(2 \mathrm{mmol})$ and alkyne 4 ( $2 \mathrm{mmol})$ in $2 \mathrm{ml}$ of acetonitrile and $1 \mathrm{ml}$ of $\mathrm{H}_{2} \mathrm{O}$, copper iodide $(0.2 \mathrm{mmol})$ was mixed at ambient temperature. The reaction mixture was stirred at room temperature for $4-8 \mathrm{~h}$ (monitored by TLC). The reaction mixture was poured into ice cold water $(10 \mathrm{ml})$, extracted with ethyl acetate $(10 \mathrm{ml})$ three times. The combined organic layer was washed with water $(10 \mathrm{ml})$, followed by brine $(10 \mathrm{ml})$, and dried over anhydrous sodium sulphate, concentrated under reduced pressure to get crude 1-(3-benzisoxazolyl)-4-aryl-1,2,3-triazoles 5, which were purified by column chromatography over silica gel (60-120 mesh) using hexane:EtOAc (8:2) as eluent.

\subsubsection{1. (4-Phenyl-1H-1,2,3-triazol-1-yl)benzo[d]isoxazole (5a)}

White solid; m.p. $88-90^{\circ} \mathrm{C}$; IR $\left(\mathrm{KBr}, \mathrm{cm}^{-1}\right)$ v 3050, 1701, 1606, 1240, 1110; ${ }^{1} \mathrm{HNMR}$ (400 MHz, DMSO-d $)_{6} \delta 9.62(\mathrm{~s}, 1 \mathrm{H}, \mathrm{Ar}-\mathrm{H}), 8.43$ (d, J=8.0 Hz, 1H, Ar-H), 8.14 (d, J=8.0 Hz, 2H, Ar-H), 8.00 (d, J=8.0 Hz, 1H, Ar-H), 7.93 (t, J=8.0 Hz, 1H, Ar-H), 7.70 (t, J=7.6 Hz, 1H, ArH), $7.50(\mathrm{t}, \mathrm{J}=7.6 \mathrm{~Hz}, 1 \mathrm{H}, \mathrm{Ar}-\mathrm{H}) ;{ }^{13} \mathrm{C}$ NMR (DMSO-d $\left.6,100 \mathrm{MHz}\right) \delta 164.9,147.1,145.6$, 130.6, 130.4, 129.2, 128.7, 127.5, 123.1, 123.0, 122.4, 122.2, 121.9: LCMS (MM:ES+APCL) 
$263.3(\mathrm{M}+\mathrm{H})^{+}$; HPLC 95\%. Anal. Calcd for $\mathrm{C}_{15} \mathrm{H}_{10} \mathrm{~N}_{4} \mathrm{O}$ : C, 68.69; H, 3.84; N, 21.36; Found: C, 68.75; H, 3.90; N, 21.41.

\subsubsection{2. (4-(p-Tolyl)-1H-1,2,3-triazol-1-yl)benzo[d]isoxazole (5b)}

White solid; m.p. $92-94^{\circ} \mathrm{C}$; IR $\left(\mathrm{KBr}, \mathrm{cm}^{-1}\right)$ v 3034, 1706, 1615, 1230, 1125; ${ }^{1} \mathrm{HNMR}$ (400 MHz, DMSO-d 6 ) $\delta 9.54(\mathrm{~s}, 1 \mathrm{H}, \mathrm{Ar}-\mathrm{H}), 8.42(\mathrm{~d}, \mathrm{~J}=8.0 \mathrm{~Hz}, 1 \mathrm{H}, \mathrm{Ar}-\mathrm{H}), 8.02$ (t, J=7.4 Hz, 3H, Ar-H), 7.92 (t, J=8.2 Hz, 1H, Ar-H), 7.69 (t, J=7.8 Hz, 1H, Ar-H), 7.39 (d, J=8.0 Hz, 2H, Ar-H), 2.42 (s, 3H, Ar-Me); ${ }^{13} \mathrm{C}$ NMR (DMSO-d $\left.6,100 \mathrm{MHz}\right) \delta 164.9,147.1,145.0,131.7$, 130.6, 129.5, 127.4, 125.7, 123.0, 122.4, 122.2, 121.9, 109.6, 21.3; LCMS (MM:ES+APCL) $277.3(\mathrm{M}+\mathrm{H})^{+}$; HPLC 95\% Anal. Calcd for $\mathrm{C}_{16} \mathrm{H}_{12} \mathrm{~N}_{4} \mathrm{O}$ : C, 69.55; H, 4.38; N, 20.28; Found: C, 69.63; H, 4.46; N, 20.34.

\subsubsection{3-(4-(3-methoxy-5-methylphenyl)-1H-1,2,3-triazol-1-yl)benzo[d]isoxazole (5c)}

White solid; m.p. $108-110^{\circ} \mathrm{C}$; IR $\left(\mathrm{KBr}, \mathrm{cm}^{-1}\right)$ v $3018,1718,1602,1236,1121 ;{ }^{1} \mathrm{HNMR}$ (400 MHz, DMSO-d 6 ) $\delta 9.19(\mathrm{~s}, 1 \mathrm{H}, \mathrm{Ar}-\mathrm{H}), 8.43(\mathrm{~d}, \mathrm{~J}=8.0 \mathrm{~Hz}, 1 \mathrm{H}, \mathrm{Ar}-\mathrm{H}), 8.00(\mathrm{~d}, \mathrm{~J}=8.0 \mathrm{~Hz}, 1 \mathrm{H}$, Ar-H,) 7.93 (t, J=8.0 Hz, 1H, Ar-H), 7.83 (d, J=8.4 Hz, 1H, Ar-H), 7.69 (t, J=7.8 Hz, 1H, ArH), 7.01 (m, 2H, Ar-H), 3.87 (s, 3H, OMe), 2.57 (s, 3H, Ar-Me); ${ }^{13}$ CNMR (DMSO-d 63,100 MHz) $\delta 164.9,161.0,147.1,145.0,139.9,133.9,130.6,123.0,122.7,122.4,122.2,121.9$, 113.1, 110.6, 109.6, 55.8, 21.9: LCMS (MM:ES+APCL) 307.1(M+H) ${ }^{+}$; HPLC 95\%. Anal.

Calcd for $\mathrm{C}_{17} \mathrm{H}_{14} \mathrm{~N}_{4} \mathrm{O}_{2}$ : C, 66.66; H, 4.61; N, 18.29; Found: C, 66.72; H, 4.68; N, 18.36.

\subsubsection{4. (4-(3,5-bis(trifluoromethyl)phenyl)-1H-1,2,3-triazol-1-yl)benzo[d]isoxazole (5d)}

White solid; m.p. $134-136^{\circ} \mathrm{C}$; IR $\left(\mathrm{KBr}, \mathrm{cm}^{-1}\right)$ v $3021,1698,1611,1215,1136 ;{ }^{1} \mathrm{HNMR}(400$ MHz, DMSO-d 6 ) $\delta 9.94$ (s, 1H, Ar-H), 8.72 (s, 2H, Ar-H), 8.32 (d, J=6.0 Hz, 1H, Ar-H), 8.14 (s, 1H, Ar-H), 7.87-7.95 (m, 2H, Ar-H), 7.59-7.65 (m, 1H, Ar-H); ${ }^{13} \mathrm{C}$ NMR (DMSO-d 6100 MHz) $\delta 164.9,147.1,145.0,133.6,131.8$ (q), 130.6, 129.8, 124.7, 123.1, 123.0, 122.4, 122.2, 
121.9, 109.6: LCMS (MM:ES+APCL) $399.86(\mathrm{M}+\mathrm{H})^{+}$; HPLC 95\%. Anal. Calcd for $\mathrm{C}_{17} \mathrm{H}_{8} \mathrm{~F}_{6} \mathrm{~N}_{4} \mathrm{O}: \mathrm{C}, 51.27 ; \mathrm{H}, 2.02 ; \mathrm{N}, 14.07$; Found: $\mathrm{C}, 51.32 ; \mathrm{H}, 2.06 ; \mathrm{N}, 14.16$.

\subsubsection{5. (4-(4-Methoxyphenyl)-1H-1,2,3-triazol-1-yl)benzo[d]isoxazole (5e)}

White solid; m.p. $96-98^{\circ} \mathrm{C}$; IR $\left(\mathrm{KBr}, \mathrm{cm}^{-1}\right)$ v 3034, 1706, 1615, 1230, $1125 ;{ }^{1} \mathrm{HNMR}$ (400 MHz, DMSO-d 6 ) $\delta 9.50(\mathrm{~s}, 1 \mathrm{H}, \mathrm{Ar}-\mathrm{H}), 8.43(\mathrm{~d}, \mathrm{~J}=8.0 \mathrm{~Hz}, 1 \mathrm{H}, \mathrm{Ar}-\mathrm{H}), 8.07$ (d, J=9.2 Hz, 2H, Ar-H), 8.01 (d, J=8.4 Hz, 1H, Ar-H), 7.93 (t, J=7.8 Hz, 1H, Ar-H), 7.69 (t, J=7.6 Hz, 1H, Ar-H), 7.15 (d, J=8.4 Hz, 2H, Ar-H), 3.89 (s, 3H, OMe); ${ }^{13} \mathrm{C}$ NMR (DMSO-d $\left.6,100 \mathrm{MHz}\right) \delta$ $164.2,159.7,152.0,147.5,132.3,127.3,125.6,123.4,121.7,118.9,114.5,113.8,110.7$, 55.2; LCMS (MM:ES+APCL) $293.3(\mathrm{M}+\mathrm{H})^{+}$; HPLC 95\%. Anal. Calcd for $\mathrm{C}_{16} \mathrm{H}_{12} \mathrm{~N}_{4} \mathrm{O}_{2}:$ C, 65.75; H, 4.14; N, 19.17; Found: C, 65.81; H, 4.19; N, 19.22.

\subsubsection{3-(4-(4-phenoxyphenyl)-1H-1,2,3-triazol-1-yl)benzo[d]isoxazole (5f) (PTB)}

White solid; m.p. $122-124^{\circ} \mathrm{C}$; IR $\left(\mathrm{KBr}, \mathrm{cm}^{-1}\right)$ v 3025, 1699, 1616, 1219, $1139 ;{ }^{1} \mathrm{HNMR}$ $\left(400 \mathrm{MHz}, \mathrm{DMSO}-\mathrm{d}_{6}\right) \delta 9.55(\mathrm{~s}, 1 \mathrm{H}, \mathrm{Ar}-\mathrm{H}), 8.41(\mathrm{~d}, \mathrm{~J}=8.0 \mathrm{~Hz}, 1 \mathrm{H}, \mathrm{Ar}-\mathrm{H}), 8.14$ (d, J=8.8 Hz, 2H, Ar-H), 7.99 (d, J=7.8 Hz, 1H, Ar-H), 7.90 (t, J=8.0 Hz, 1H, Ar-H), 7.68 (t, J=7.8 Hz, 1H, Ar-H), 7.47 (t, J=7.6 Hz, 2H, Ar-H), 7.13-7.24 (m, 5H, Ar-H); ${ }^{13} \mathrm{C}$ NMR (DMSO-d 6 , 100 MHz) $\delta 164.9,157.0,147.1,145.0,130.6,128.9,128.4,127.2,123.2,123.0,122.4,122.2$, 121.9, 121.8, 118.9, 118.0, 109.6: LCMS (MM:ES+APCL) 355.5 (M+H)+;HPLC 95\%. Anal. Calcd for $\mathrm{C}_{21} \mathrm{H}_{14} \mathrm{~N}_{4} \mathrm{O}_{2}$ : C, 71.18; H, 3.98; N, 15.81; Found: C, 71.22; H, 4.03; N, 15.88.

\subsection{Pharmacology}

\subsubsection{Cell Culture}

Myeloid leukemia cell lines MOLM13 and MV4-11 were kind gifts by Dr. Martin Grundy (Department of Academic Haematology, University of Nottingham). MOLM14 cells were generously provided by Dr. Didier Bouscary (Department of Hematology-Immunology, 
Institut Cochin, Paris, France). Cell lines were cultured and maintained in RPMI medium containing $10 \%$ fetal bovine serum (FBS) and $1 \%$ penicillin-streptomycin (Invitrogen, Carlsbad, CA) at $37{ }^{\circ} \mathrm{C}$ in a humidified atmosphere with $5 \% \mathrm{CO}_{2}$. All cell lines were regularly screened for absence of mycoplasma. Bone marrow cells from C57BL/6 mice were cultured in IMDM supplemented with $20 \%$ FBS and cytokines (10 $\mathrm{ng} / \mathrm{ml}$ recombinant mouse IL-3, $10 \mathrm{ng} / \mathrm{ml}$ recombinant mouse IL-6 and $50 \mathrm{ng} / \mathrm{ml}$ recombinant mouse Stem Cell Factor (SCF)).

\subsubsection{Cell proliferation assay}

Cellular proliferation of AML cell lines was examined by using methylthiazolyldiphenyl-tetrazolium bromide (MTT; Sigma-Aldrich) as described previously. ${ }^{34}$ Briefly, 8,000 cells per well were seeded in triplicate in 96-well plates (Corning, Lowell, MA, USA) in $100 \mu 1$ of medium containing different concentrations of new compounds. Cells were incubated overnight at $37^{\circ} \mathrm{C}$ in a $\mathrm{CO}_{2}$ incubator. At the end of the culture duration, 3-(4, 5dimethylthiazol-2-yl)-2, 5-diphenyltetrazolium bromide (MTT) was added into each well until the final concentration of MTT in each well was $0.5 \mathrm{mg} / \mathrm{ml}$. MTT plates were incubated at $37{ }^{\circ} \mathrm{C}$ in a $\mathrm{CO}_{2}$ incubator for $3 \mathrm{~h}$. After incubation, Formazan crystals were dissolved in $100 \mu \mathrm{l}$ of stop solution (SDS-HCl). Absorbance was measured at $570 \mathrm{~nm}$ using a Tecan Infinite 200 PRO spectrophotometer (Mannedorf, Switzerland).

\subsubsection{Flow cytometric analysis}

To determine the effect of PTB on the cell cycle, cells were treated with PTB at the indicated time points as described previously. ${ }^{35,36}$ Briefly, cells were washed twice with cold phosphate-buffered saline (PBS) and fixed with $70 \%$ ethanol (precooled at $-20{ }^{\circ} \mathrm{C}$ ) at $4{ }^{\circ} \mathrm{C}$. Cells were incubated with propidium iodide (PI) solution $(50 \mu \mathrm{g} / \mathrm{ml}$ PI, $1 \%$ Triton X-100, 20 $\mu \mathrm{g} / \mathrm{ml}$ DNase-free RNase A in PBS for $30 \mathrm{~min}$ at $37^{\circ} \mathrm{C}$ in the dark. Cell distribution across 
the cell cycle was analyzed by an LSR-II flow cytometer (Becton- Dickinson, San Jose, CA, USA).

\subsubsection{Annexin $\mathrm{V}$ and propidium iodide (Annexin V-PI) apoptosis analysis}

Annexin V-PI staining was performed using flow cytometry as described earlier. ${ }^{34,} 37$ Briefly, 100,000 cells were incubated in 6-well plate with different concentrations of PTB for 72 h. Staining was carried out using the FITCI Annexin V Apoptosis Detection Kit II (BD Biosciences, USA). Cells were washed with ice-cold PBS without $\mathrm{Ca}^{2+}$ or $\mathrm{Mg}^{2+}$ (Life Technologies), resuspended in $100 \mu 11 \mathrm{X}$ binding buffer and incubated with $5.0 \mu \mathrm{l}$ of PI and 3 $\mu \mathrm{l}$ annexin V FITCI for $15 \mathrm{~min}$ in dark. The samples were immediately analyzed by LSR-II flow cytometer (BD, San Jose, CA, USA).

\subsubsection{Immunoblot analysis}

Western blotting was performed using antibodies against p21, acetylated-tubulin, tubulin cyclin D, Beta actin, cleaved PARP and cleaved caspase-9 (Cell Signalling, Boston, MA, USA) as described earlier. ${ }^{38}$

\subsubsection{Acid extraction of histones and histones acetylation}

Acid extraction of histones was performed as described previously. ${ }^{39}$ Briefly, MV4-11 cells were suspended in $5 \mathrm{ml}$ of PBS containing $1 \mathrm{X}$ protease inhibitor and centrifuged at 1000 rpm for $5 \mathrm{~min}$ at $4{ }^{\circ} \mathrm{C}$, and the supernatant was discarded. Pellets were resuspended in $5 \mathrm{ml}$ of pre-chilled Buffer A (10 mM Tris pH 8.0, $10 \mathrm{mM}$ EDTA, $0.5 \mathrm{mM}$ EGTA, $0.25 \%$ Triton X100) for $10 \mathrm{~min}$. After centrifugation, pellets were washed with $5 \mathrm{ml}$ of Buffer B (10 mM Tris $\mathrm{pH}$ 8.0, $1 \mathrm{mM}$ EDTA, $0.5 \mathrm{mM}$ EGTA, $0.2 \mathrm{M} \mathrm{NaCl}$ ) and resuspended in $30 \mathrm{mM}$ Tris $\mathrm{pH}$ 7.4, $50 \mathrm{mM}$ EDTA buffer, and sulphuric acid was added to a final concentration of $0.24 \mathrm{M}$. Samples were incubated on ice for $2 \mathrm{~h}$ and centrifuged at 13,000 rpm for $15 \mathrm{~min}$. Acetone was added into the supernatant, and samples were incubated overnight. The next day, 
histones were pelleted, air died and resuspended in distilled water containing protease inhibitor. The protein concentration was determined using Bradford's reagent (Bio-Rad Protein Assay; Cat. No. 500-0006). The extracted histones were aliquoted and stored at -70 ${ }^{\circ} \mathrm{C}$. Histones $(0.5 \mu \mathrm{g})$ were loaded onto Tris-Glycine $4-20 \%$ gradient gels (Thermo Scientific), electrophoresed and transferred to PVDF membranes. The membranes were blocked in $5 \%$ milk and incubated with anti-acetyl-Histone $\mathrm{H} 3$ antibody (Merck Millipore) at 1:1000 dilutions in blocking buffer (5\% milk) overnight at $4{ }^{\circ} \mathrm{C}$ on a rocker shaker. Membranes were washed with PBS-Tween-20 and incubated with HRP conjugated secondary antibody for $1 \mathrm{~h}$. Blots were developed using ECL reagent (Thermo Scientific). Anti-histone H3 antibody (Cell signaling) was used as loading control.

\section{Results and Discussion}

\subsection{Synthesis of the scaffold benzisoxazole azide and its triazole derivatives.}

The synthesis of the key intermediate benzisoxazole-3-azide 3 is outlined in Figure 1A. The benzisoxazole amine 2 was prepared as described previously ${ }^{40}$ by the reaction of acetohydroxamic acid with 2 -flurobenzonitrile $\mathbf{1}$ in the presence of potassium tertiary butoxide in DMF. Then, the benzisoxazole-3-amine 2 was diazotised followed by in situ aromatic nucleophilic substitution by sodium azide to get benzisoxazole-3-azide 3 .

With the key intermediate benzisoxazole-3-azide 3 in hand, 1-(3-benzisoxazolyl)-4aryl-1,2,3-triazoles 5a-f were synthesized through Copper (I)-catalyzed azide-alkyne cycloaddition (CuAAC) with various alkynes 4 (Figure 1A). Thus, 1-(3benzisoxazolyl)triazoles 5a-f bearing phenyl, 4-methoxyphenyl, 4-methylphenyl, 3,5ditrifluromethylphenyl, 3-methoxy-5-methylphenyl and 4-phenoxyphenyl groups at 4position were obtained in $82-92 \%$ yield (Table 1). The structures of all the synthesized compounds 5a-f were confirmed by spectral and microanalytical analysis. All final 
compounds 5a-f showed a characteristic singlet around $9.6 \delta$ corresponding to a proton on the triazole ring.

Figure 1
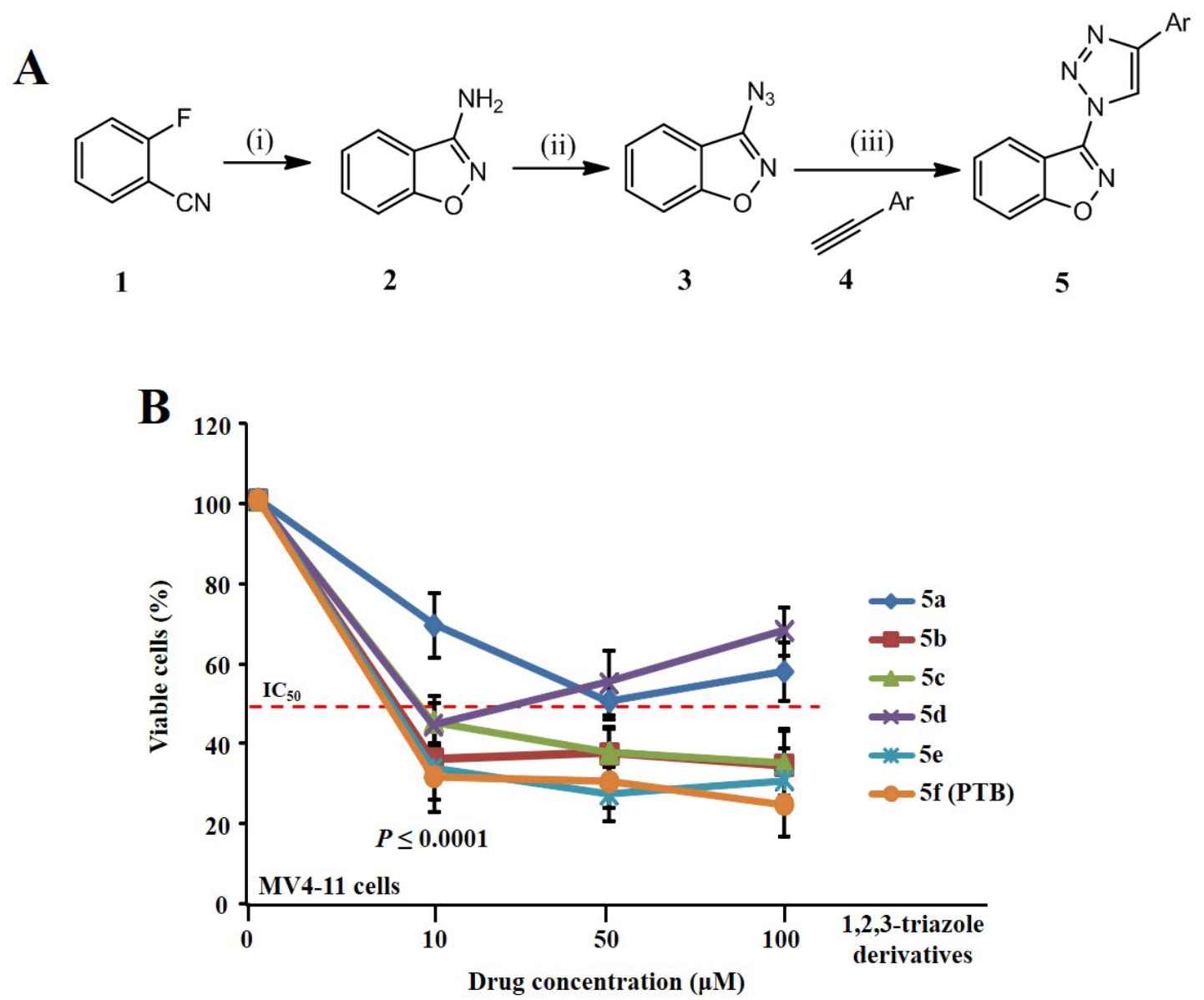

Figure 1. A, Schematic representation of the synthesis of 1-(3-benzisoxazolyl)-4-aryl-1,2,3triazoles. Reagents and conditions: (i) Acetohydroxamic acid, t-BuOK, DMF, rt. (ii) Conc. $\mathrm{HCl}, \mathrm{H}_{2} \mathrm{O}, \mathrm{NaNO}_{2}, \mathrm{NaN}_{3}, 0^{\circ} \mathrm{C}$. (iii) CuI, acetonitrile: $\mathrm{H}_{2} \mathrm{O}$ (2:1). $B$, MTT assays were performed after incubation of MV4-11 cells with the indicated concentrations of triazole derivatives $5 \mathrm{a}-\mathrm{f}$ for $72 \mathrm{~h}$. For each concentration, percent inhibition values were calculated and data was normalized to diluent controls. Data represent mean $\pm \mathrm{SD}$ from three independent experiments done in quadruplicates. 
Table 1. Structures of 1-(3-benzisoxazolyl)-4-aryl-1,2,3-triazoles (5a-f)

\begin{tabular}{|c|c|c|c|}
\hline Sl. No. & $\mathrm{Ar}(\mathbf{4 , 5})$ & $\mathbf{5}$ & \% Yield 5 \\
\hline 1 & $\mathrm{C}_{6} \mathrm{H}_{5}$ & $\mathbf{5 a}$ & 90 \\
\hline 2 & $4-\mathrm{MeC}_{6} \mathrm{H}_{4}$ & $\mathbf{5 b}$ & 85 \\
\hline 3 & $3-\mathrm{MeO}-5-\mathrm{MeC}_{6} \mathrm{H}_{3}$ & $\mathbf{5 c}$ & 92 \\
\hline 4 & $3,5-\left(\mathrm{CF}_{3}\right)_{2} \mathrm{C}_{6} \mathrm{H}_{3}$ & $\mathbf{5 d}$ & 90 \\
\hline 5 & $4-\mathrm{MeOC}_{6} \mathrm{H}_{4}$ & $\mathbf{5 e}$ & 88 \\
\hline 6 & $\mathrm{C}_{5} \mathrm{H}_{5} \mathrm{OC}_{6} \mathrm{H}_{4}$ & $\mathbf{5 f}$ & 82 \\
& & & \\
\hline
\end{tabular}

\subsection{PTB suppresses cellular proliferation of AML cells in a dose and time dependent} manner

Initially we investigated the antiproliferative activity of all compounds against an AML cell line (MV4-11) at different concentration (10, 50 and $100 \mu \mathrm{M})$ using the MTT assay. Among the tested compounds, PTB was found to be most active among the 1,2,3triazoles synthesized, exhibiting an $\mathrm{IC}_{50}$ value of $2 \mu \mathrm{M}$ (see Fig. $1 \mathrm{~B}$ for all activities obtained). PTB was further evaluated on a panel of three AML cell lines including MOLM13, MOLM14 and MV4-11 cells. PTB displayed a significant reduction in the number of viable cells in all the tested cell lines in a dose- and time-dependent manner (Fig. 2) with the $\mathrm{IC}_{50}$ of $1 \mu \mathrm{M}, 2 \mu \mathrm{M}$ and $2.5 \mu \mathrm{M}$ at 96 hours against MOLM13, MOLM14 and MV4-11 respectively. However, PTB did not show a cytotoxic effect on the normal bone marrow cells up to $72 \mathrm{~h}$ at $5 \mu \mathrm{M}$ and $10 \mu \mathrm{M}$ concentrations in liquid culture indicating that the PTB does not have cytotoxic effect on normal cell (Fig. 3). 
Figure 2
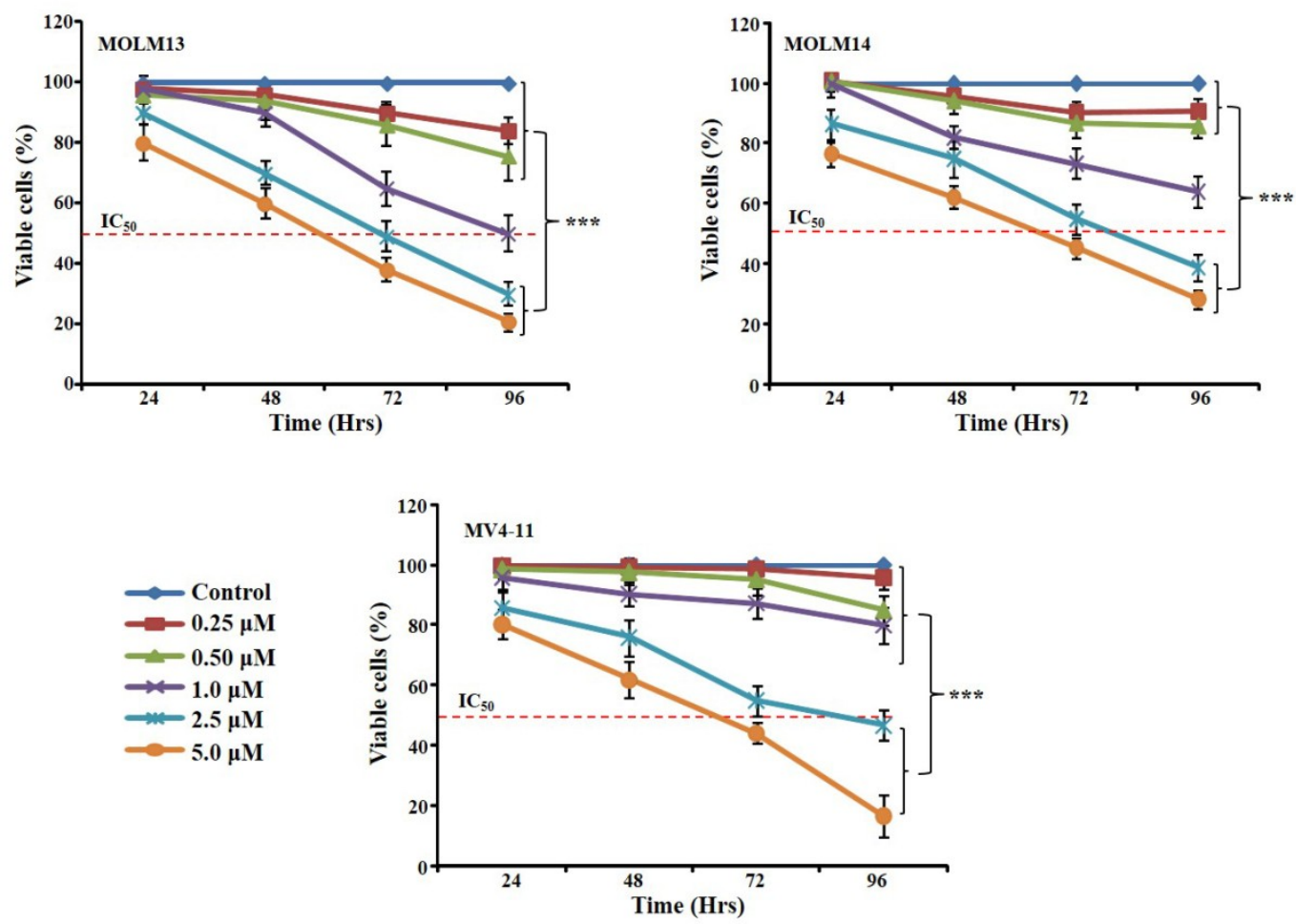

Figure 2. Cytotoxic effect of PTB against AML cell lines in liquid culture. Panels $(\mathrm{A}-\mathrm{C})$ : PTB displayed a significant reduction in the number of viable cells in MOLM13, MOLM14 and MV4-11 cells in a dose- and time-dependent manner. Dotted red line indicates $\mathrm{IC}_{50}$ and $* * *$, p value $<0.0001$

Figure 3

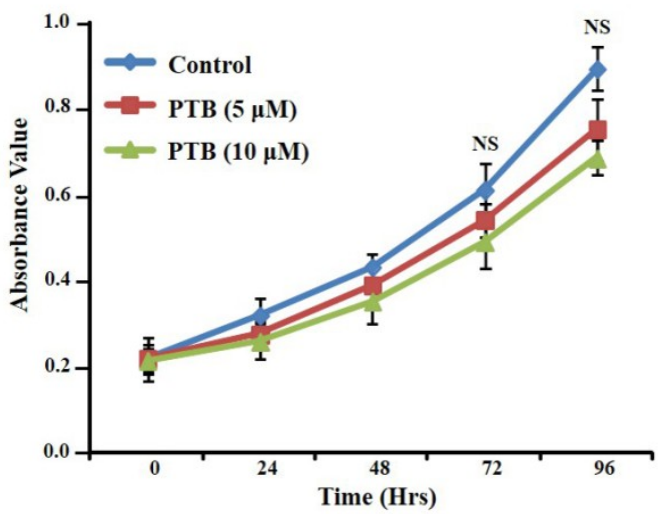

Figure 3. Antiproliferative effect of compound PTB (5, $10 \mu \mathrm{m}$ PTB against C57BL/6 mouse bone marrow cells in liquid culture). MTT assay determined cell viability of C57BL/6 mouse 
total bone marrow cells. Results represent the mean \pm SD of three independent experiments with quadruplicate wells per experiment point. NS represents statistically no significant difference between control and $5 \mu \mathrm{M} / 10 \mu \mathrm{M}$ PTB.

\subsection{PTB leads to cell cycle arrest in AML cells}

We next evaluated the effect of PTB on the cell cycle distribution of MOLM13, MOLM14 and MV4-11 cells using flow cytometric analysis. MOLM13, MOLM14 and MV4-11 cells were treated with PTB up to $72 \mathrm{~h}$ and analyzed cell cycle distribution after propidium iodide staining. Interestingly, we at longer time interval observed the arrest of cell cycle at G2/M phase along with accumulation of AML cells at sub-G1 phase (Fig. 4), while the percentage of cells in G1 phase decreased marginally after treatment.
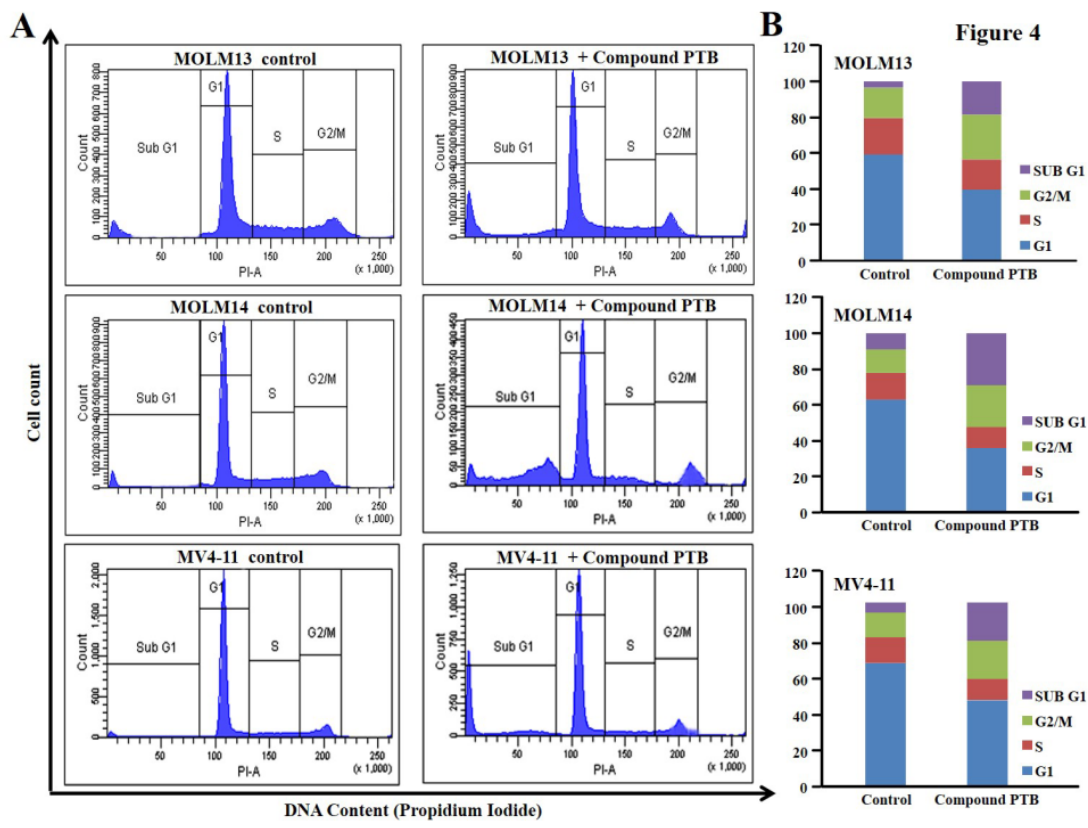

Figure 4. PTB leads to cell cycle arrest in AML cells. $A$, Fluorescent activated cell sorter analyzed the percent MOLM13, MOLM14 and MV4-11 cells in each phase of the cell cycle. Arrest of cell cycle at G2/M phase along with accumulation sub-G1 phase was observed PTB treatment gradually decreased the percentage of AML cells in G1 phase. The figures are 
representative of three independent experiments. $B$, Data are presented in histograms as mean \pm SD of three independent experiments.

\subsection{PTB induces apoptosis of AML cells}

To determine the mechanistic origin of PTB on apoptosis, MOLM13, MOLM14 and MV4-11 cells were treated with different concentrations $(2.5,5.0$ and $10 \mu \mathrm{M})$ of PTB for $72 \mathrm{~h}$ and examined for apoptosis using annexin-V (AV) combined with propidium iodide (PI) staining. Flow cytometric analysis clearly showed dose-dependent increase in the percentage of apoptotic cells in all the cell lines (Fig. 5A). Next, we examined whether PTB treatment induced apoptosis in a caspase-dependent manner. For this, MOLM13 cells were treated with varying doses of PTB for $24 \mathrm{~h}$ and western blotting was performed for cleaved caspase- 9 and cleaved PARP (poly ADP ribose polymerase). It was found that PTB induced cleaved PARP and caspase-9 in a dose-dependent manner (see Fig. 5B), thereby indicating its mechanism via an intrinsic apoptotic pathway.

A

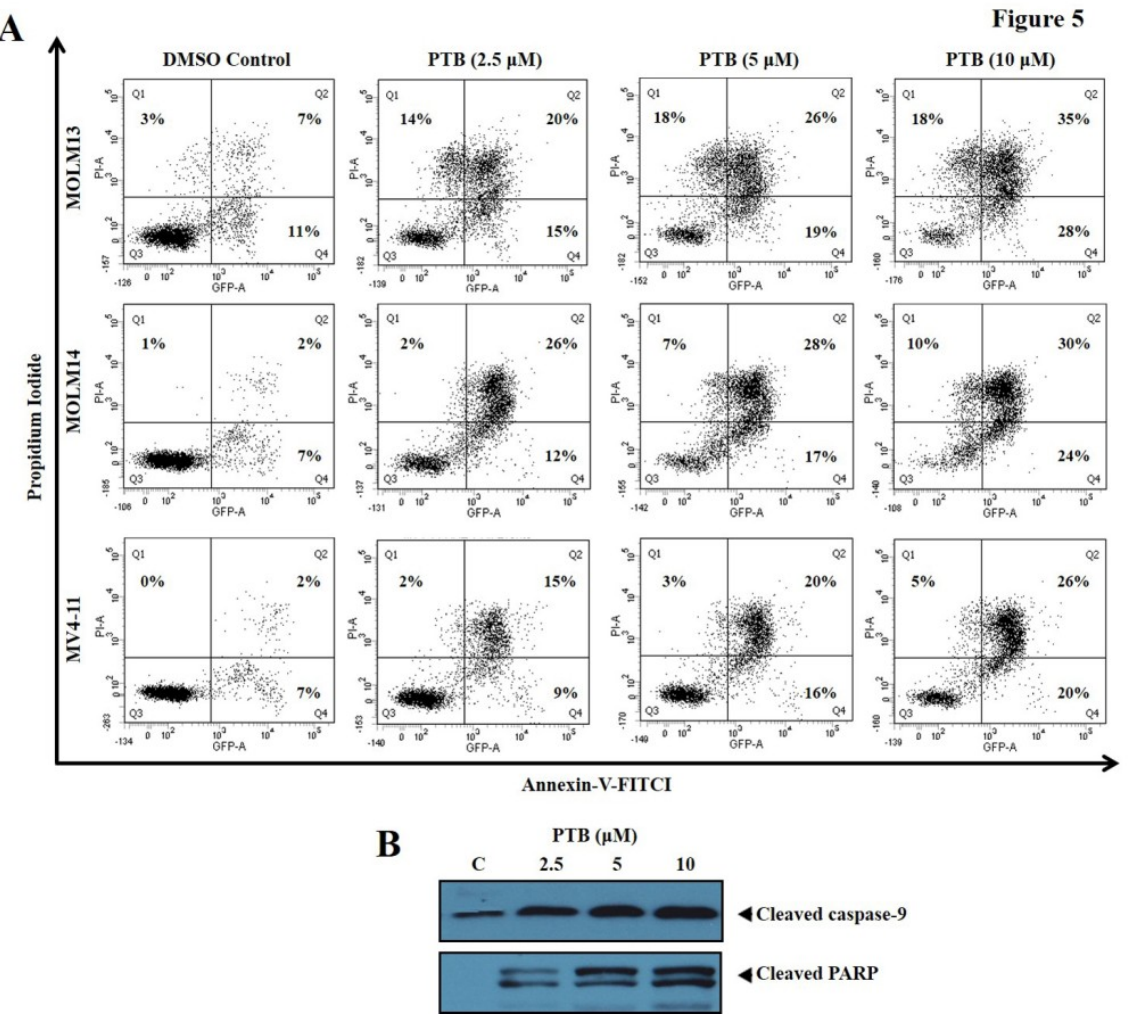


Figure 5. Flow cytometry profile upon PTB treatment (Annexin V-FITC staining on the Xaxis vs. PI staining on the Y-axis). The upper left quadrants display the necrotic cells, upper right quadrants show the late apoptotic cells, lower left quadrants display the live cells and lower right quadrants show the early apoptotic cells. It can be seen that PTB induces apoptosis of AML cells in a dose-dependent manner. $B$, Western blot analysis shows increased expression of cleaved caspase- 9 and cleaved PARP protein in PTB treated AML cells (MOLM13, MOLM14 and MV4-11) compared to control cells.

Since experimental data suggests DNA damage induced by our compounds, we investigated potential direct molecular interactions between DNA and 1,2,3-triazoles. Small molecules allow two types of non-covalent interactions with DNA: groove binding and intercalation. ${ }^{41}$ DNA minor groove binders usually show characteristic shapes and at least two positive charges carried by nitrogen atoms, ${ }^{42}$ which are not at all present in our compound series. Therefore, we focused our analyses on potential DNA intercalation and performed an in silico docking campaign using the co-crystal structure of DNA and the prototypical intercalator actinomycin D (PDB: 173D) as template structure. ${ }^{43}$ After ensuring successful redocking of the actinomycin $\mathrm{D}$, we docked all compounds to the intercalation site and found clearly less favourable docking scores than for the cognate ligand. Our compound series of heterocycles lacks appropriate polycycles for classical intercalation, thus leading to fewer Van der Waals contacts and less $\pi$-stacking interactions with the DNA base pairs. We therefore assume that direct DNA interaction plays only a minor role in the biological function of our compounds.

\subsection{In silico mode of action analysis of PTB that targets HDAC6}

In order to understand the mode-of-action of PTB on a molecular level, with respect to its abilities of interacting with proteins and modulating pathways involved in apoptosis, we subsequently predicted potential protein targets for the series of 1,2,3-triazole derivatives 
using a Laplacian-modified Naïve Bayes classifier trained on 155,000 protein-ligand annotations extracted from ChEMBL. ${ }^{44}$ We identified potential targets based on classspecific cut-offs and found different members the family of histone deacetylases (HDACs) consistently predicted for all six compounds. This is a target family known to be involved in apoptosis modulation, ${ }^{45}$ which we hence decided to follow up first in a structure-based manner, in order to gain more support for our hypothesis that PTB targets HDACs on the interaction level, and subsequently also to confirm the predictions experimentally.

\subsection{In silico molecular interaction studies of PTB on HDACs.}

Our in silico mode-of-action analysis for the compound PTB revealed that it targets HDACs. Previous studies have reported that the diazide-containing isoxazoles were used to target histone deacetylases. ${ }^{46}$ Additionally, 3-substituted-1,2-isoxazole was reported to show potent inhibitory activity against HDAC6. ${ }^{47}$ On the other hand, the second deacetylase domain of HDAC6 possesses tubulin deacetylase activity, ${ }^{48}$ therefore, we focussed on this domain. In absence of an experimental structure, we relied on a homology model from SWISS-MODEL ${ }^{49}$ that was based on an HDAC4 structure (PDB: 2VQW, sequence identity $=$ $47 \%) .{ }^{50}$ We selected the $\mathrm{Zn}^{2+}$ ion as well as its coordinating residues (D649, H651, D742) as the centre of the docking sphere and required coordination to the metal ion for all poses taken into account further. Docking was performed using MOE's default parameters. ${ }^{51}$

We observed virtually identical pose predictions for the complete compound series. The benzisoxazole and triazole substructures are predicted to coordinate to the active site metal ion (Fig. 6). All compounds show a high degree of shape complementarity to the binding site of HDAC6, forming multiple molecular interactions in the hydrophobic region as well as a hydrogen bond to the phenol side-chain of Tyr-782. Compared to the co-crystal structures of HDAC2 inhibitors N-(2-aminophenyl)benzamide (PDB: $3 \mathrm{MAX})^{52}$ and the prototypical inhibitor suberanilohydroxamic acid SAHA (PDB: 4LXZ) ${ }^{53}$ similar regions of 
the binding site are explored including the HDAC foot pocket. The point of variation explored in our series is predicted to occupy a solvent-exposed region, thus explaining the observed rather flat structure-activity relationship.

\section{Figure 6}

A

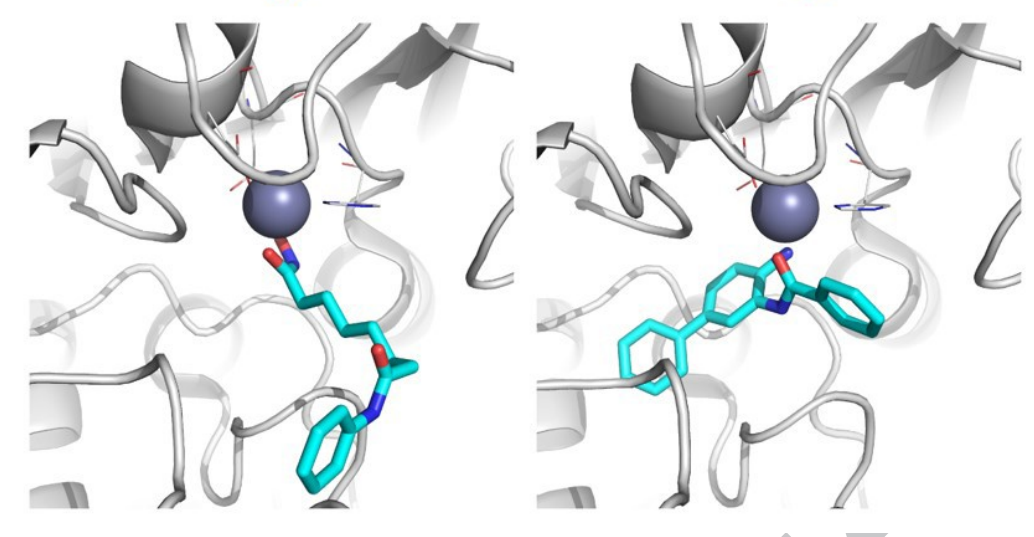

C

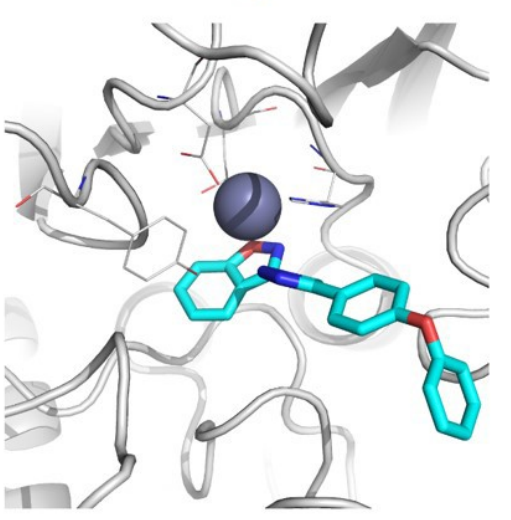

Figure 6. Molecular interactions of HDAC inhibitors: $A$, Molecular interactions between HDAC2 and the covalent hydroxamate inhibitor SAHA (PDB: 4LXZ). The protein is shown as grey cartoon with the catalytic zinc ion as sphere. Coordinating residues are highlighted as thin lines, the bound inhibitor as sticks in elemental colors with carbon in cyan. $B$, Binding pose of N-(2-aminophenyl)benzamide in the HDAC2 binding site (PDB: 3MAX). $C$, The predicted binding mode of PTB in the HDAC6 active site shows a high degree of overlap with co-crystal structures of HDAC2 inhibitors. The inhibitor exploits both the foot pocket as well as the classic hydrophobic binding site region and forms an additional hydrogen bond to Tyr-782 (shown as thin lines in C). Structure-based mode-of-action analysis therefore suggests HDACs as the target of PTB to induce apoptosis consistent with ligand.

\subsection{PTB induces acetylation of tubulin and expression of $\mathbf{p} 21$ protein}

On the other hand, HDIs have been reported to inhibit deacetylation of non-histone proteins such as tubulin. ${ }^{10,54}$ The major substrate for HDAC6 is tubulin and it functions as tubulin deacetylase removing acetylation at lysine $40 .{ }^{55}$ Based on this observation we next 
evaluated whether PTB treatment enhanced the acetylation of tubulin at lysine 40 . Western blot analysis showed that treatment of AML cells with PTB resulted in increased acetylation of tubulin at lysine 40, thereby suggesting that PTB may inhibit HDAC6 (Fig. 7A). The build-up of acetylated tubulin stabilizes the microtubules and disturb the chromosomal alignment during mitosis to induce apoptosis. ${ }^{13}$

Several studies furthermore reported that HDIs including suberoylanilide hydroxamic acid (SAHA), trichostatin A (TSA), FR901228 and oxamflatin induce the expression of p21. ${ }^{8}$ Therefore, we examined the effect of PTB on the expression of p21 in AML cells. In our western blot data, we observed that PTB treatment indeed also induces protein expression of p21 (Fig. 7A). Further, reports suggested that HDIs downregulate cyclin D and induce p21 to arrest cells in early G1 phase. Therefore, we examined the effect of PTB on cyclin D in MOLM13 cells. We observed the decline in the levels of cyclin D in dose-dependent manner with maximum inhibition at $10 \mu \mathrm{M}$ (Fig. 7B). The decrease in cyclin $\mathrm{D}$ is unexpected, because cyclin D is known to arrest cell cycle at G1 phase which is contradictory to our flow cytometry analysis results. However, the previous report suggested that, FR901228 is a histone deacetylase inhibitor which downregulates cyclin D1 and arrest cell cycle at G2/M phase. The contradictory downregulation of cyclin D1 was explained by the inhibitory effects of FR901228 on histone deacetylase. ${ }^{56}$

\subsection{PTB increases histone modification}

Previous studies have demonstrated that the inhibition of HDACs leads to increase in acetylation of histone $\mathrm{H} 3$ acetylation at lysine $9(\mathrm{H} 3 \mathrm{~K} 9)$ and histone $\mathrm{H} 3$ acetylation at lysine 14 (H3K14). Based on the above ligand-based and structure-based in silico mode-of-action hypotheses, we next investigated the effect of our lead compound on H3K9. It was found that PTB treatment significantly increased the acetylation of $\mathrm{H} 3$ in a dose-dependent manner. However, PTB had no effect on expression of total histone H3 protein expression (Fig. 7C). 
The results evidently support our in silico prediction and demonstrates the interference of PTB with HDAC activity

Figure 7

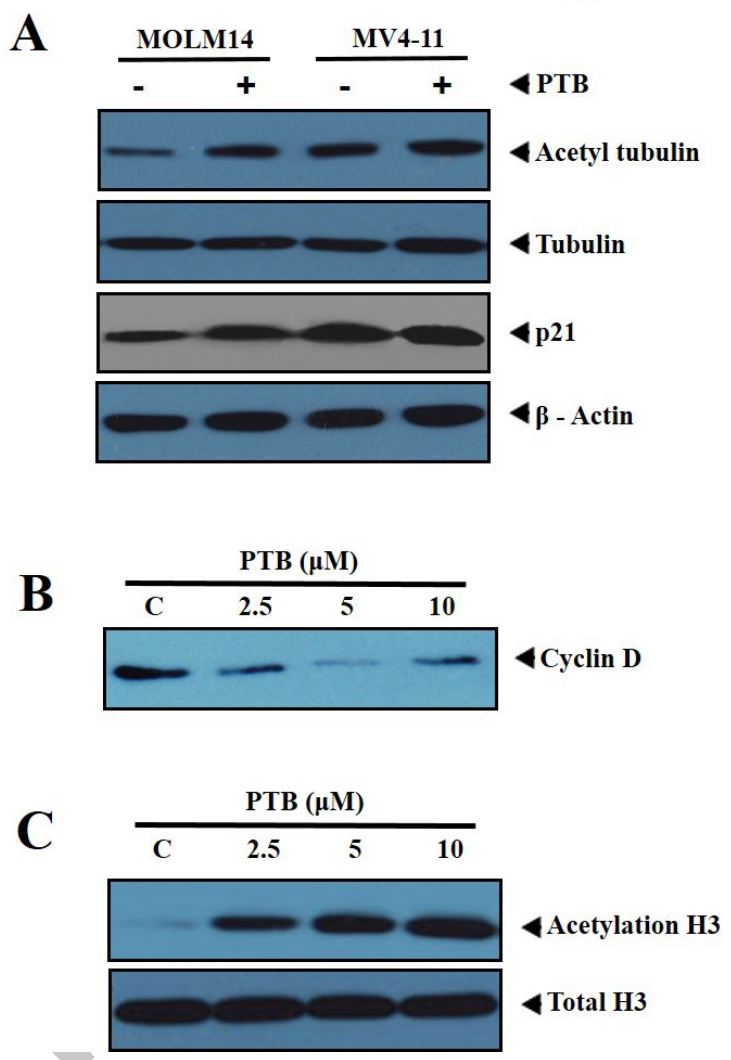

Figure 7. $A$, Western blot analysis showing increased expression of $\mathrm{p} 21$ and acetylation of tubulin in PTB treated AML cells. $B$, Western blot analysis showing decreased expression of Cyclin D in PTB treated AML cells. $C$, Western blot analysis showing increased acetylation of histone $\mathrm{H} 3$ in PTB treated AML cells

\section{Conclusions}

The discovery of the HDAC family of proteins, and avenues of how to modulate them, has provided a new dimension to the design of therapeutic agents against a broad range of cancers via epigenetics approaches. In the present study, a series of novel 1,2,3-triazoles have been synthesized and evaluated biologically. PTB was identified as the most potent cytotoxic agent against various AML cell lines (MOLM13, MOLM14 and MV4-11 cells), 
while showing selectivity over bone marrow stem cells. Ligand-based as well as structurebased analysis of the interaction partners suggested HDACs as a molecular mode-of-action of PTB, which has been confirmed in experiment. The lead compound PTB hence significantly decreased cell proliferation, induced mitochondrial-mediated apoptosis, and disrupted the cell cycle of MOLM13, MOLM14 and MV4-11 cells. Our computational analysis suggested HDAC as the target of PTB, which has been validated by increased acetylation of histone $\mathrm{H} 3$ in a dose-dependent manner, as well as induction of p21 and tubulin acetylation.

\section{Acknowledgements}

The authors are grateful to the Board of Research in Nuclear Sciences (BRNS projects vide No. 2009/37/40/BRNS/2266 dated 23-11-2009), Institution of Excellence, University of Mysore for financial support to KSR. NA thanks the Council for Scientific and Industrial Research-University Grants Commission (CSIR-UGC) for senior research fellowship, and CDM thanks Department of Science and Technology-Promotion of University Research and Scientific Excellence (DST-PURSE) Research Associate fellowship. AB thanks the European Research Commission for funding.

\section{References and Notes}

1. Keerthy, H. K.; Mohan, C. D.; Sivaraman Siveen, K.; Fuchs, J. E.; Rangappa, S.; Sundaram, M. S.; Li, F.; Girish, K. S.; Sethi, G.; Basappa; Bender, A.; Rangappa, K. S. The Journal of biological chemistry 2014, 289, 31879.

2. Chen, H. P.; Zhao, Y. T.; Zhao, T. C. Critical reviews in oncogenesis 2015, 20, 35.

3. Daniel, M.; Tollefsbol, T. O. The Journal of experimental biology 2015, 218, 59.

4. Ma, J.; Guo, X.; Zhang, S.; Liu, H.; Lu, J.; Dong, Z.; Liu, K.; Ming, L. Molecular medicine reports 2015, 11, 4525.

5. Glozak, M. A.; Seto, E. Oncogene 2007, 26, 5420.

6. Chu, Q. S.; Nielsen, T. O.; Alcindor, T.; Gupta, A.; Endo, M.; Goytain, A.; Xu, H.; Verma, S.; Tozer, R.; Knowling, M.; Bramwell, V. B.; Powers, J.; Seymour, L. K.; Eisenhauer, E. A. Annals of oncology : official journal of the European Society for Medical Oncology / ESMO 2015, 26, 973.

7. Walfridsson, J.; Khorosjutina, O.; Matikainen, P.; Gustafsson, C. M.; Ekwall, K. The EMBO journal 2007, 26, 2868.

8. Blagosklonny, M. V.; Robey, R.; Sackett, D. L.; Du, L.; Traganos, F.; Darzynkiewicz, Z.; Fojo, T.; Bates, S. E. Molecular cancer therapeutics 2002, 1, 937.

9. Beckers, T.; Burkhardt, C.; Wieland, H.; Gimmnich, P.; Ciossek, T.; Maier, T.; Sanders, K. International journal of cancer. Journal international du cancer 2007, 121, 1138. 
10. Acharya, M. R.; Sparreboom, A.; Venitz, J.; Figg, W. D. Molecular pharmacology 2005, 68, 917.

11. Akilov, O. E.; Geskin, L. Skin therapy letter 2011, 16, 1.

12. Robey, R. W.; Chakraborty, A. R.; Basseville, A.; Luchenko, V.; Bahr, J.; Zhan, Z.; Bates, S. E. Molecular pharmaceutics 2011, 8, 2021.

13. Dowdy, S. C.; Jiang, S.; Zhou, X. C.; Hou, X.; Jin, F.; Podratz, K. C.; Jiang, S. W. Molecular cancer therapeutics 2006, 5, 2767.

14. Odds, F. C.; Brown, A. J.; Gow, N. A. Trends in microbiology 2003, 11, 272.

15. Kale, P.; Johnson, L. B. Drugs of today (Barcelona, Spain : 1998) 2005, 41, 91.

16. Geisler, J.; Lonning, P. E. The Journal of steroid biochemistry and molecular biology 2005, 95,

75.

17. Howell, A.; Buzdar, A. The Journal of steroid biochemistry and molecular biology 2005, 93,

237.

18. Kim, D.-K.; Kim, J.; Park, H.-J. Bioorganic \& medicinal chemistry letters 2004, 14, 2401.

19. Whiting, M.; Tripp, J. C.; Lin, Y.-C.; Lindstrom, W.; Olson, A. J.; Elder, J. H.; Sharpless, K. B.; Fokin, V. V. Journal of medicinal chemistry 2006, 49, 7697.

20. Jain, M.; Kwon, C. H. J Med Chem 2003, 46, 5428.

21. Sadashiva, M. P.; Basappa, S.; Nanjundaswamy, S.; Li, F.; Manu, K. A.; Sengottuvelan, M.; Prasanna, D. S.; Anilkumar, N. C.; Sethi, G.; Sugahara, K.; Rangappa, K. S. BMC chemical biology 2012, $12,5$.

22. Newsome, J. J.; Hassani, M.; Swann, E.; Bibby, J. M.; Beall, H. D.; Moody, C. J. Bioorganic \& medicinal chemistry 2013, 21, 2999.

23. Chandra, J. N. S.; Malviya, M.; Sadashiva, C.; Subhash, M.; Rangappa, K. S. Neurochemistry international 2008, 52, 376.

24. Novak, M.; Rangappa, K. S.; Manitsas, R. K. The Journal of Organic Chemistry 1993, 58, 7813.

25. Bharathkumar, H.; Paricharak, S.; Dinesh, K.; Siveen, K. S.; Fuchs, J. E.; Rangappa, S.; Mohan, C.; Mohandas, N.; Kumar, A. P.; Sethi, G. RSC Advances 2014, 4, 45143.

26. Bharathkumar, H.; Mohan, C. D.; Ananda, H.; Fuchs, J. E.; Li, F.; Rangappa, S.; Surender, M.; Bulusu, K. C.; Girish, K. S.; Sethi, G. Bioorganic \& medicinal chemistry letters 2015.

27. Sathya, R.; Swamy, J.; Ramesh, S.; Dhananjaya, M.; Nanjundaswamy, A.; Bhadraiah, H.; Zameer, F.; Subbaiah, G.; Subbegowda, R. Medicinal chemistry (Shariqah (United Arab Emirates)) 2014.

28. Rangaswamy Roopashree, T. R. S., Swamy Jagadish, Chakrabhavi Dhananjaya Mohan, Kanchugarakoppal Subbegowda Rangappa. Letters in Drug Design \& Discovery 2014, 11, 1143.

29. Mantelingu, K.; Sadashiva, M.; Rangappa, K. Indian journal of chemistry. Sect. B: Organic chemistry, including medical chemistry 2004, 43, 1954.

30. Rangappa, K. S.; Basappa. Journal of Physical Organic Chemistry 2005, 18, 773.

31. Sugahara, K.; Thimmaiah, K. N.; Bid, H. K.; Houghton, P. J.; Rangappa, K. S. PloS one 2012, 7, e39444.

32. Fongmoon, D.; Shetty, A. K.; Basappa; Yamada, S.; Sugiura, M.; Kongtawelert, P.; Sugahara, K. The Journal of biological chemistry 2007, 282, 36895.

33. Anusha, S.; Anandakumar, B. S.; Mohan, C. D.; Nagabhushana, G. P.; Priya, B. S.; Rangappa, K. S.; Basappa; T, C. G. RSC Advances 2014, 4, 52181.

34. Keerthy, H. K.; Garg, M.; Mohan, C. D.; Madan, V.; Kanojia, D.; Shobith, R.; Nanjundaswamy, S.; Mason, D. J.; Bender, A.; Basappa; Rangappa, K. S.; Koeffler, H. P. PloS one 2014, 9, e107118.

35. Garg, M.; Okamoto, R.; Nagata, Y.; Kanojia, D.; Venkatesan, S.; M, T. A.; Braunstein, G. D.; Said, J. W.; Doan, N. B.; Ho, Q.; Akagi, T.; Gery, S.; Liu, L. Z.; Tan, K. T.; Chng, W. J.; Yang, H.; Ogawa, S.; Koeffler, H. P. The Journal of clinical endocrinology and metabolism 2015, 100, 725.

36. Mohan, C. D.; Bharathkumar, H.; Bulusu, K. C.; Pandey, V.; Rangappa, S.; Fuchs, J. E.; Shanmugam, M. K.; Dai, X.; Li, F.; Deivasigamani, A.; Hui, K. M.; Kumar, A. P.; Lobie, P. E.; Bender, A.; Basappa; Sethi, G.; Rangappa, K. S. The Journal of biological chemistry 2014, 289, 34296. 
37. Hayano, T.; Garg, M.; Yin, D.; Sudo, M.; Kawamata, N.; Shi, S.; Chien, W.; Ding, L. W.; Leong, G.; Mori, S.; Xie, D.; Tan, P.; Koeffler, H. P. Journal of experimental \& clinical cancer research : CR 2013, 32, 17.

38. Neelgundmath, M.; Dinesh, K. R.; Mohan, C. D.; Li, F.; Dai, X.; Siveen, K. S.; Paricharak, S.; Mason, D. J.; Fuchs, J. E.; Sethi, G.; Bender, A.; Rangappa, K. S.; Kotresh, O.; Basappa. Bioorganic \& medicinal chemistry letters 2015, 25, 893.

39. Madan, V.; Madan, B.; Brykczynska, U.; Zilbermann, F.; Hogeveen, K.; Dohner, K.; Dohner, H.; Weber, O.; Blum, C.; Rodewald, H. R.; Sassone-Corsi, P.; Peters, A. H.; Fehling, H. J. Blood 2009, 113, 1444.

40. Palermo, M. Tetrahedron letters 1996, 37, 2885.

41. Gurova, K. Future oncology (London, England) 2009, 5, 1685.

42. Fuchs, J. E.; Spitzer, G. M.; Javed, A.; Biela, A.; Kreutz, C.; Wellenzohn, B.; Liedl, K. R. Journal of chemical information and modeling 2011, 51, 2223.

43. Kamitori, S.; Takusagawa, F. Journal of the American Chemical Society 1994, 116, 4154.

44. Koutsoukas, A.; Lowe, R.; Kalantarmotamedi, Y.; Mussa, H. Y.; Klaffke, W.; Mitchell, J. B.; Glen, R. C.; Bender, A. Journal of chemical information and modeling 2013, 53, 1957.

45. Facchetti, F.; Previdi, S.; Ballarini, M.; Minucci, S.; Perego, P.; Porta, C. A. M. L. Apoptosis 2004, 9, 573.

46. Neelarapu, R.; Holzle, D. L.; Velaparthi, S.; Bai, H.; Brunsteiner, M.; Blond, S. Y.; Petukhov, P. A. J Med Chem 2011, 54, 4350.

47. Kozikowski, A. P.; Tapadar, S.; Luchini, D. N.; Kim, K. H.; Billadeau, D. D. J Med Chem 2008, 51,4370 .

48. Haggarty, S. J.; Koeller, K. M.; Wong, J. C.; Grozinger, C. M.; Schreiber, S. L. Proceedings of the National Academy of Sciences of the United States of America 2003, 100, 4389.

49. Kiefer, F.; Arnold, K.; Kunzli, M.; Bordoli, L.; Schwede, T. Nucleic acids research 2009, 37, D387.

50. Bottomley, M. J.; Lo Surdo, P.; Di Giovine, P.; Cirillo, A.; Scarpelli, R.; Ferrigno, F.; Jones, P.; Neddermann, P.; De Francesco, R.; Steinkuhler, C.; Gallinari, P.; Carfi, A. The Journal of biological chemistry 2008, 283, 26694.

51. Molecular Operating Environment (MOE), C. C. G. I.; Montreal, Q., Canada, 2013.

52. Bressi, J. C.; Jennings, A. J.; Skene, R.; Wu, Y.; Melkus, R.; De Jong, R.; O'Connell, S.; Grimshaw, C. E.; Navre, M.; Gangloff, A. R. Bioorganic \& medicinal chemistry letters 2010, $20,3142$.

53. Lauffer, B. E.; Mintzer, R.; Fong, R.; Mukund, S.; Tam, C.; Zilberleyb, I.; Flicke, B.; Ritscher, A.; Fedorowicz, G.; Vallero, R.; Ortwine, D. F.; Gunzner, J.; Modrusan, Z.; Neumann, L.; Koth, C. M.; Lupardus, P. J.; Kaminker, J. S.; Heise, C. E.; Steiner, P. The Journal of biological chemistry 2013, 288, 26926.

54. Bhalla, K. N. Journal of Clinical Oncology 2005, 23, 3971.

$55 . \quad$ Aldana-Masangkay, G. I.; Sakamoto, K. M. Journal of Biomedicine and Biotechnology 2011, $2011,10$.

56. Sandor, V.; Senderowicz, A.; Mertins, S.; Sackett, D.; Sausville, E.; Blagosklonny, M. V.; Bates, S. E. British journal of cancer $2000,83,817$. 
Graphical abstract

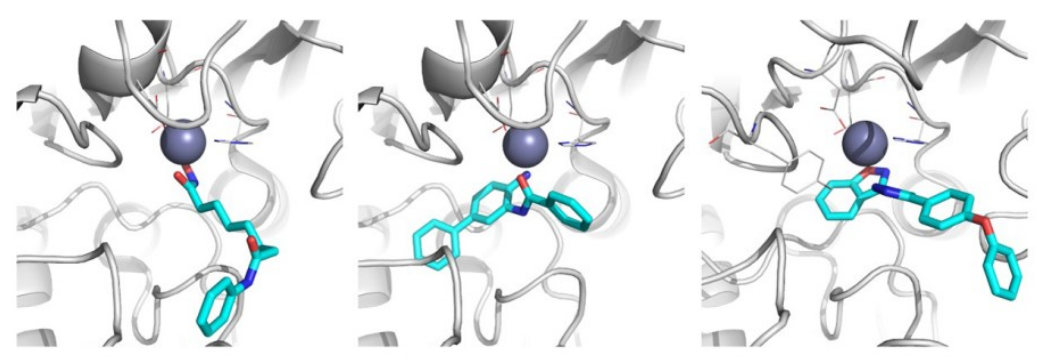




\section{Highlights}

- We here describe the coupling of 1,2,3-triazoles to the third position of a 1,2benzisoxazole via Copper (I)-catalyzed azide-alkyne cycloaddition (CuAAC) with various alkynes.

- PTB has been identified as the lead cytotoxic compound against the AML cell lines.

- An apoptotic effect of PTB was demonstrated using Annexin-V staining and flow cytometry analysis.

- In silico analysis suggested Histone Deacetylases as the mode-of-action of PTB which has been experimentally validated by showing acetylation patterns in target proteins and examining expression of $\mathrm{p} 21$. 